\title{
Recorregut de recerca geològica i minera per la comarca del Priorat: des de Falset a Marçà, al Masroig, al Molar i a la Figuera de Falset
}

Josep Maria Mata-Perelló

Joaquim Sanz Balagué

\section{XARAGALL \\ REVISTA DE CIÈNCIES DE LA CATALUNYA CENTRAL} ก. 6

JUNY 2015 


\title{
RECORREGUT DE RECERCA GEOLÒGICA I MINERA PER LA COMARCA DEL PRIORAT: DES DE FALSET A MARÇÀ, AL MASROIG, AL MOLAR I A LA FIGUERA DE FALSET
}

\author{
Josep Maria Mata-Perelló \\ Museu de geologia Valentí Masachs, Escola Politècnica Superior d'Enginyeria de Manresa \\ (EPSEM), Universitat Politècnica de Catalunya - BarcelonaTech (UPC), 08272 Manresa, Spain
}

\section{Joaquim Sanz Balagué}

Departament d'Enginyeria Minera i Recursos Naturals (EMRN), Escola Politècnica Superior d'Enginyeria de Manresa (EPSEM), Universitat Politècnica de Catalunya . BarcelonaTech (UPC), 08272 Manresa, Spain

Paraules clau: Sistema Mediterrani, Patrimoni miner

\begin{abstract}
Resum
Itinerari realitzat el 29 de juny de 2014. En aquesta ocasió, el recorregut del present itinerari discorrerà íntegrament, per una sola de les tres unitats geològiques que constitueixen Catalunya: concretament per la coneguda com a Sistema Mediterrani. Dintre d'aquesta, el recorregut recalarà, també exclusivament en una sola de les seves sotsunitats, la més externa de totes: la Serralada Prelitoral Catalana. Així, en aquest recorregut, observarem clarament les alineacions "catalanes" (NNE-SSW); tot i així, veurem la influència de les alineacions ibèriques (WNW-ESE), en algunes de les fractures que anirem trobant al llarg de l'itinerari.
\end{abstract}

Tot i així, prop del Molar veure una altra sotsunitat: la Depressió de Mora. Aquesta es situa entre les dues branques en que es divideix la Serralada Prelitoral Catalana cap a ponent, a partir d'aquesta comarca. Aquesta unitat, també la veurem en el recorregut des del Masroig al Molar.

Així, el recorregut s'iniciarà prop de la població de Falset, des d'on s'anirà cap a Marçà, dintre ja de l'esmentada Serralada Prelitoral Catalana, per la qual anirà circulant fins a la fi del recorregut de l'itinerari, en arribar a la població de la Figuera de Falset, on finalitzarà el recorregut de l'itinerari.

Per altra banda, aquest itinerari discorrerà per una sola comarca: la del Priorat, des dels voltants de Falset i Marçà fins a la Figuera de Falset, on clourà el recorregut del mateix. Aquesta comarca s'inclou a cavall de les denominades Terres de l'Ebre, i de les Terres de Reus. 


\section{Objectius fonamentals}

Al llarg del present recorregut, si s'escau, s'intentaran aconseguir el següents objectius fonamentals.

1. Estudi i observació dels materials paleozoics (del Carbonífer, fonamentalment), els quals constitueixen la Serralada Prelitoral Catalana, entre els quals discorrerà part del recorregut de l'itinerari. Aquests materials de vegades seran granodiorites, en altres ocasions seran esquistos, pissarres o lidites, segons els indrets per on transiti el recorregut de l'itinerari.

2. Estudi i observació dels materials mesozoics (del Triàsic exclusivament, en bona part del Buntsandstein i del Muschelkalk Inferior), que formen part de la Serralada Prelitoral Catalana, dintre del recorregut de l'itinerari, especialment pels voltants de del Molar i de la Figuera de Falset. Aquests materials, de vegades seran gresos (als afloraments dels terrenys del Buntsandstein) i de vegades materials carbonatats (als afloraments del Muschelkalk).

3. Observació, a distancia de la Depressió de Mora, situada entre les dues branques en les que es subdivideix la Serralada Prelitoral Catalana. Aquesta depressió es troba reblerta de sediments cenozoics de l'Eocè; tot i que als darrers trams ja pertanyen a l'Oligocè.

4. Observació en aquesta zona de les interferències entre les alineacions "catalanes" (NNESSW) i les "ibèriques" (WNW-ESE), dintre de la Serralada Prelitoral Catalana. Aquestes darreres direccions es manifesten fonamentalment a les fractures a les quals van associades les mineralitzacions.

5. Observació, a distancia dels contactes entre la Serralada Prelitoral Catalana i la Depressió de Mora. Aquests contactes els podem veure, a llarga distancia, en el recorregut del Masroig al Molar.

6. Estudi de diverses mineralitzacions situades entre els materials paleozoics i mesozoics de la Serralada Prelitoral. Entre aquestes, farem esment de les següents, d'acord amb l'ordre de desenvolupament del recorregut:

6A) de les mineralitzacions filonianes de $\mathrm{Pb}-\mathrm{Zn}$, que anirem trobant a diversos indrets del recorregut pel Priorat, i en especial pels termes del Masroig i del Molar, encaixades entre en molts dels indrets entre els materials paleozoics del Carbonífer.

6B) de les mineralitzacions filonianes de Baritina, que trobarem al terme municipal del Molar (Priorat), encaixades entre roques granítiques.

6C) si s'escau de es mineralitzacions estratiformes de $M n$, situades entre els afloraments bassals del Carbonífer, que trobarem a la darrera aturada del recorregut, dintre del terme del Molar (Priorat). Aquestes mineralitzacions estratiformes es relacionen amb els nivells de "lidites" del Carbonífer.

6D) i si s'escau també, de les mineralitzacions manganesíferes de rebliment de cavitats kàstiques, que trobarem a la Figuera de Falset, entre les calcaries del Muschelkalk.

7. Observació d'algunes explotacions mineres antigues (i més recents), com les situades als indrets esmentats dintre de l'apartat anterior, ubicades dintre de la Serralada Prelitoral Catalana.

8. Observació de les tasques de restauració, si s'escau, efectuades sobre les explotacions anteriors. Tot i així, cal dir que les restauracions han estat sempre esporàdiques. 
9. Observació dels diferents indrets relacionats amb el Patrimoni Geològic, que es vagin trobant al llarg del present itinerari. En aquest sentit, cal fer esment del patrimoni mineralògic de la Mina Serrana, com a conseqüència de la presència de la PIROXMANGUITA.

10. Observació dels diferents indrets relacionats amb el Patrimoni Miner, que es vagin trobant al llarg del present itinerari.

\section{Antecedents}

$\mathrm{Hi}$ ha molts antecedents d'itineraris que coincideixen parcial o totalment amb el que ara presentem. Entre ells, farem esment dels nostres recorreguts: MATA-PERELLÓ (1996, 1997, 1998a, 1998b, 1998c, 1998d, 1999, 2000a, 2000b, 2001, 2002, 2003, 2004a. 2004b, 2005, 2008, 2010, 2011 i 2012).

Pel que fa als antecedents bibliogràfics relatius a les mineralitzacions que veurem al llarg del recorregut, cal fer esment d'un interessant treball; concretament de MELGAREJO i DRAPER (1992), referit a les diferents mineralitzacions de les comarques reusenques. Un altre antecedent es troba en MATA-PERELLÓ (1991), referit a les diferents mineralitzacions i indicis als minerals del conjunt de les comarques de Catalunya, i conseqüentment de la del Priorat.

Pel que fa als trets de la geologia d'aquestes comarques, ens referirem de nou al treball de MELGAREJO i DRAPER (1992); així com a les publicacions de I'IGME (1974, 1978a, 1978b i 1978c). Per d'altra banda, també farem esment de dos treballs referits al conjunt dels Països Catalans. Es tracta dels de: GUIMERÀ et altri (1992) i de RIBA et altri (1979).

Tots aquests treballs esmentats, i d'altres, figuraran per ordre alfabètic a l'apartat dedicat a les REFERÈNCIES BIBLIOGRÀFIQUES.

\section{Recorregut de l'itinerari}

El recorregut del present itinerari començarà a la població de Falset (la capital comarcal), des d'on s'anirà cap a Marçà, per on es farà la primera aturada. Per anar-hi, s'agafarà la carretera local T -300.

Tot seguit es dirigirà cap el Masroig, utilitzant les carreteres T - 353, N - 420 i T - 734, successivament. En aquesta població, es farà una nova aturada i tot seguit s'anirà cap a la propera població del Molar (seguint la carretera T - 734), després de sobrepassar el riu Ciurana. Poc abans de sobrepassar-lo es farà una nova aturada.

En aquest recorregut, pels voltants del Molar, es realitzaran dues noves aturades, a antigues instal-lacions mineres, Concretament, i si s'escau a la Mina Mineralogia, a la Mina Jalapa, a la Mina Raimunda i finalment a la Mina Linda Mariquita, situada molt prop del poble del Molar.

Finalment, el recorregut es dirigirà cap a la Figuera de Falset, per on es farà la darrera aturada. Així, prop d'aquesta població clourà el recorregut del present itinerari, totalment realitzat per la comarca del Priorat. En aquest cas, per anar del Molar a la Figuera de Falset, s'utilitzarà la carretera $T-730$. 


\section{Advertiments previs}

Com en altres recorreguts de RECERCA GEOLÒGICA I MINERALÒGICA... si es disposa del temps suficient, poden efectuar-se passant per totes les parades i filloles. En cas contrari, recomanem prescindir de les anomenades PARADES - CONDICIONALS.

També cal demanar. abans de començar el recorregut de l'itinerari, quin es l'estat de les pistes i dels camins per on discorrerà, en algun dels seus trams. En algun cas, es situaran en aquests trams PARADES CONDICIONALS, en funció dels vehicles que facin els recorreguts. Aquest serà el cas dels camins d'aproximació a algunes de les mines que veurem en aquest itinerari.

Per altra banda, recomanem tenir una cura extrema de la NATURA, evitant qualsevol forma d'agresió sobre ella, o de fer-n'hi un mal ús del que en ofereix la nostra mare Terra.

\section{Descripció de l'itinerari}

Com de costum, estructurarem el recorregut de l'itinerari en una sèrie de PARADES, que tot seguit anirem veient. En cada una d'aquestes aturades farem un breu comentari (geològic 0 mineralògic, segons s'escaigui).

En cada cas indicarem, entre parèntesi el full topogràfic del "Mapa Topogràfico Nacional" a escala 1:50.000 on es troba l'aturada, que en aquest cas serà sempre algun dels següents dos fulls: $\mathbf{4 7 1}$ (dit també de Mora) i $\mathbf{4 7 2}$ (dita de Reus). Aquests fulls han estat publicats per I'Instituto Geografico y Catastral de España.

Així doncs, la relació ordenada de les aturades que composen aquest itinerari, és la següent:

\subsection{Parada 1. TURÓ DE MARÇÀ, (terme municipal Marçà, comarca del Priorat). (Full 471).}

El recorregut de l'itinerari cal iniciar-lo a la localitat de Falset (la capital comarcal del Priorat). Des d'aquí, caldrà agafar la carretera local T - 300, per tal d'anar cap al peus del poble de Marçà. Aquest es troba situat a la Serralada Prelitoral Catalana, dintre de la comarca del Priorat. Aquí, doncs, farem la primera aturada. Així, des de l'inici, haurem recorregut uns $4 \mathrm{Km}$, aproximadament.

Cal dir que en aquest recorregut, així com pels voltants del poble de Marçà, veurem per tot arreu, com a la vora de la carretera uns afloraments de granits i granodiorites força alterats $i$ transformats en sauló. Tot i així, el poble de Marçà es troba al peu d'un turó en el que afloren els nivells triàsics del Buntsandstein. Aquests es troben constituïts per gresos rogencs que formen un interessant "relieve en cuesta". 


\subsection{Parada 2 - CONDICIONAL. POBLAT DEL PUIG-ROIG DEL ROGET, (terme municipal del Masroig, comarca del Priorat). (Full 471).}

Des de la parada anterior, cal anar agafar la carretera local T - 353, per tal d'anar cap a la carretera N-420, amb la finalitat de continuar després cap el proper poble del Masroig; així, haurem d'agafar la carretera local T - 734. Aquí, si s'escau, ens cal seguir per un camí que condueix cap a Bellmunt del Priorat; i tot seguit (per la dreta del camí anterior) un altre camí que ens durà al poblat del Puig-roig del Roget. Aquí, si s'escau, es pot fer una parada, a uns 6 $\mathrm{Km}$ de l'anterior, aproximadament.

En aquest recorregut, hem anat trobant els materials ja esmentats a la parada anterior. Així, hem trobat inicialment afloraments granítics.. Més endavant, en aquest recorregut, hem anat creuant molt sovint els materials detrítics, corresponents als mantells al-luvionars quaternaris que vergeixen sobre la Depressió de Mora, situada a ponent de la carretera. Més endavant, en arribar a l'indret de l'aturada, haurem trobat uns materials grisencs, de tonalitats rogenques, els quals formen part dels afloraments triàsics del Buntsandstein. (fotografia 2).

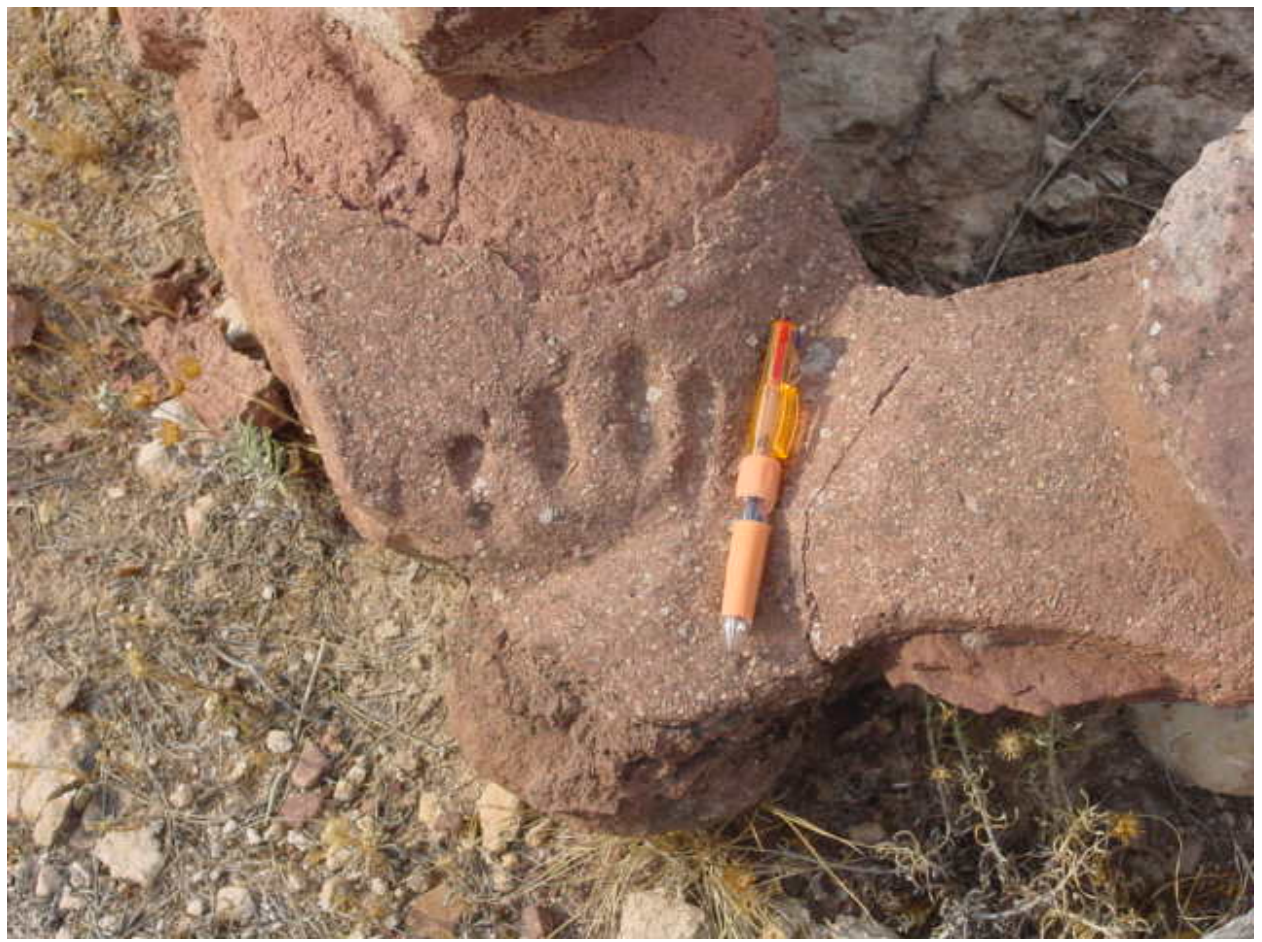

Fotografia 1. Un aspecte dels gresos rogencs del Buntsandstein.

Poblat Ibèric del Puig Roig del Roget. El Masroig

En aquest indret hi ha un poblat iber. Sembla ser que hi vivien miners i metal-lúrgics que treballaven a les Mines del Priorat (segons els plafons del poblat, i segons comunicació verbal de Margarida Genera). El poblat es troba molt ben arreglat i es força interessant de visitar-ho. Es troba sobre un aflorament dels gresos rogencs del Buntsandstein, per sobre del riu Ciurana. 


\subsection{Parada 3. CARRETERA T - 734, TRAM DEL MASROIG AL MOLAR, IMMEDIACIONS DE LA MINA SANT JOSEP, (terme municipal del Masroig, comarca del Priorat). (Full 471).}

Des de la parada anterior, cal retornar cap al Masroig, Aquí, cal seguir per la carretera que es va cap al Molar, la T - 734. A uns $2 \mathrm{Km}$ del poble, abans d'arribar al riu Ciurana, podem fer una nova aturada. Així, haurem recorregut uns 4 Km més.

En aquest recorregut, després de retornar al Masroig, hem anat trobant materials detrítics, corresponents als mantells al-luvionars quaternaris que vergeixen sobre la Depressió de Mora, situada a ponent de la carretera. Precisament, des d'aquest indret, es pot tindre una bona visió de l'esmentada depressió. (fotografía 2).

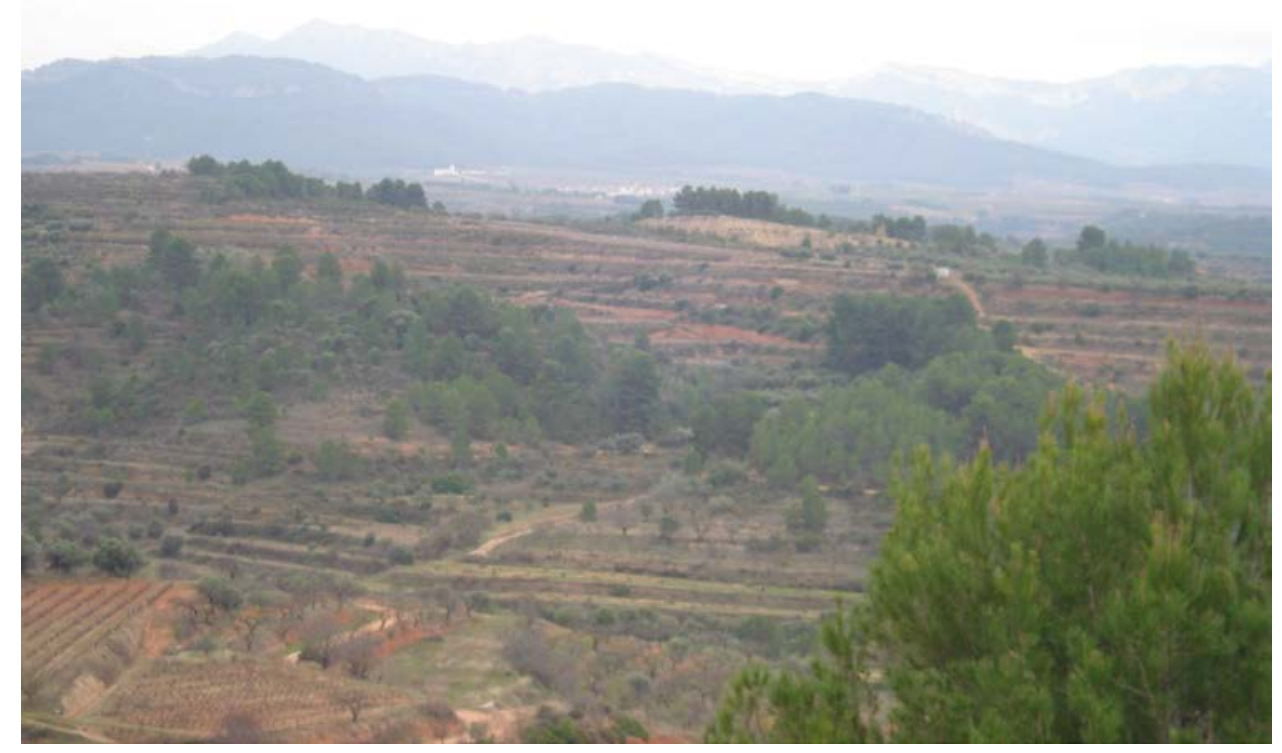

Fotografia 2. Un aspecte de la Depressió de Mora, des de les immediacions del Masroig. Al fons es veuen les Serres de Cavalls i de Pàndols. Al centre, es veuen els materials rogencs cenozoics que reblen la depressió 


\subsection{Parada 4 - CONDICIONAL. INSTAL-LACIONS DE LA MINA SANT JOSEP, (terme municipal del Masroig, comarca del Priorat). (Full 471).}

Des de la parada anterior, cal retornar cap al Masroig, Aquí, cal seguir per la carretera que es va cap al Molar. Per aquesta carretera ens caldrà arribar al riu Ciurana. Poc abans de passar-lo farem una nova aturada, a unes antigues instal-lacions mineres. Així, des de la parada anterior, haurem efectuat un trajecte de poc més de $1^{\prime} 2 \mathrm{Km}$, per tal d'arribar a aquest lloc.

En aquest recorregut hem anat trobant materials detrítics, corresponents als mantells al.luvionars quaternaris que vergeixen sobre la Depressió de Mora, situada a ponent de la carretera. Sovint, per sota d'aquests terrenys es troben els nivells paleozoics del Carbonífer, com ara succeeix a l'indret de la present aturada.

En aquest indret, a la vora del Siurana, hi ha les instal-lacions de l'antiga Mina de Sant Josep. Aquesta es localitza sobre unes mineralitzacions filonianes de $\mathrm{Pb}-\mathrm{Zn}$, que es troben encaixades entre els materials paleozoics del Carbonífer.

Entre els minerals present, cal fer esment dels anteriors, en especial de l'ESFALERITA i de la GALENA. Ambdós es troben a l'antiga escombrera. Conjuntament amb ells també hi ha GOETHITA (terrosa i limonítica), molt abundant.

Entre les instal-lacions mineres, cal fer esment d'un pou perillós; així com de les restes dels edificis miners.

\subsection{Parada 5. MINA SERRANA, (terme municipal del Molar, comarca del Priorat). (Full 471).}

Després de fer la parada anterior, cal seguir cap el Molar. Poc després de sobrepassar el riu, trobarem (a uns $2 \mathrm{Km}$ i escaig) un camí cimentat que es dirigeix cap al Clos Berenguer. Tot i que és un camí privat, el podem seguir. Aquest camí ens durà a l'indret on hi ha la Mina Serrana, aquí farem una nova aturada, a uns $4 \mathrm{~km}$ de l'anterior. Tot i això, cal demanar autorització, per circular per aquest camí.

En aquest recorregut, hem trobat uns nivells de gresos i de margues ocres que pertanyen a I'Eocè, i es situen a la Depressió de Mora, per on transitarem molt tangencialment. Aquests materials es troben en bona part recoberts pel Quaternari. Després, (ja de nou dintre de la Serralada Prelitoral Catalana), i agafar el camí que condueix a la mina, a la qual anem, es comencen de nou a trobar els materials paleozoics del Carbonífer, constituïts per nivells de quarsites i d'esquistos, els quals es troben situats per sota dels del Buntsandstein.

Aquesta mina, (en la qual s' han extret minerals de manganès, per a ésser utilitzats com a pedres semiprecioses), es situa sobre d'una mineralització vulcano - sedimentària de $\mathrm{Mn}$ associada a nivells de "chert", que es localitza entre els materials de la base del Carbonífer

Entre els minerals presents, cal fer esment dels següents: PIROLUSITA, PSILOMELANA, PIROXMANGUITA, QUARS i RODONITA. Entre ells, els que s'explotaven eren els dos silicats esmentats del manganès: la piroxmanguita i la rodonita.

Actualment, debut a la implantació de nous cultius vinícoles, s' han dut a terme moltes obres a la zona. Tot i així, encara es possible entrar a una de les galeries, però, cal tenir una extremada cura, si s'entra, ja que les mines es troben en precàries condicions de seguretat, i els minerals poden trobar-se a les escombreres. (fotografíes 3 i 4). 


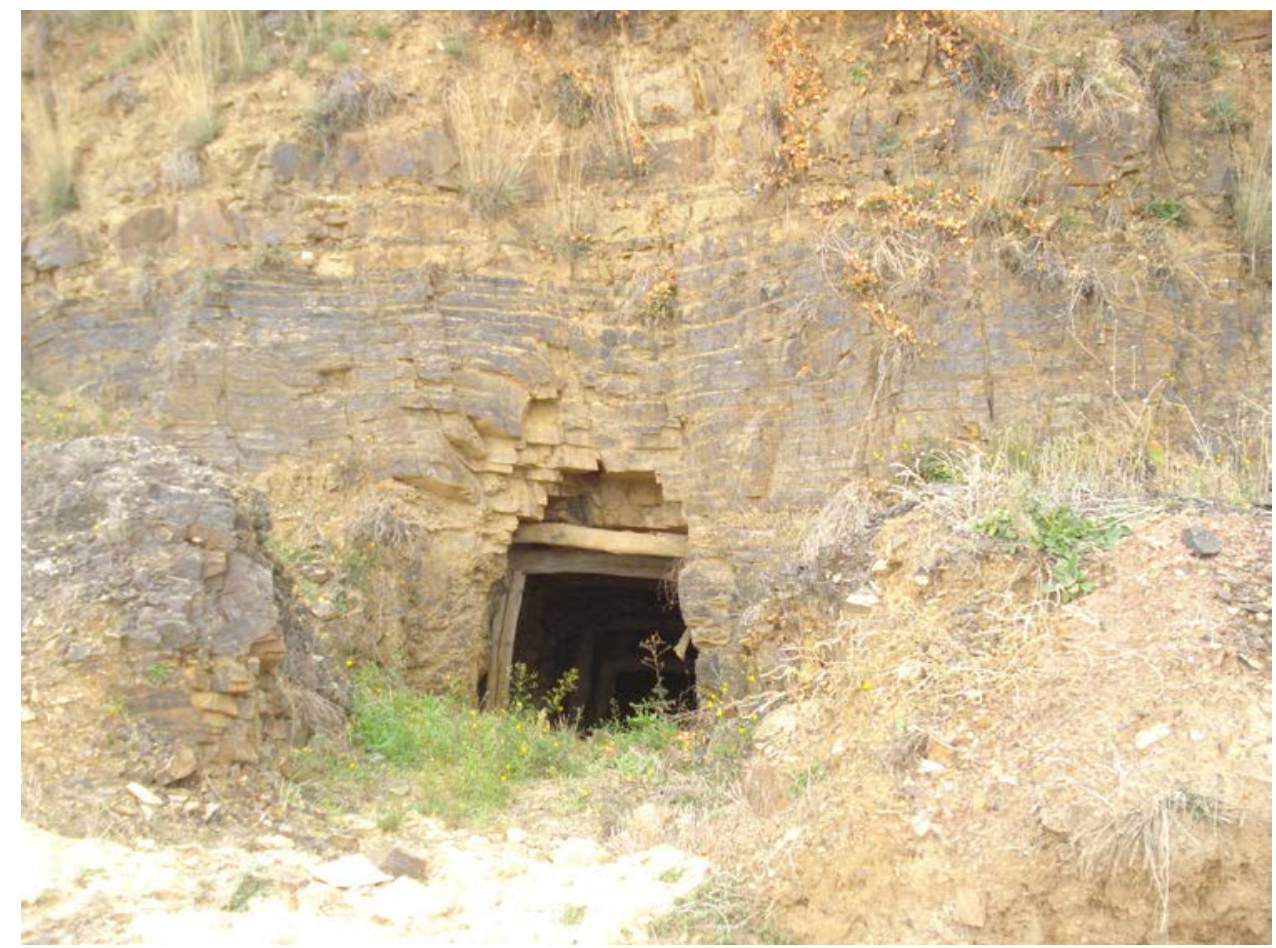

Fotografia 3. Bocamina de la Mina Serrana, entre afloraments de lidites del Carbonífer. El Molar

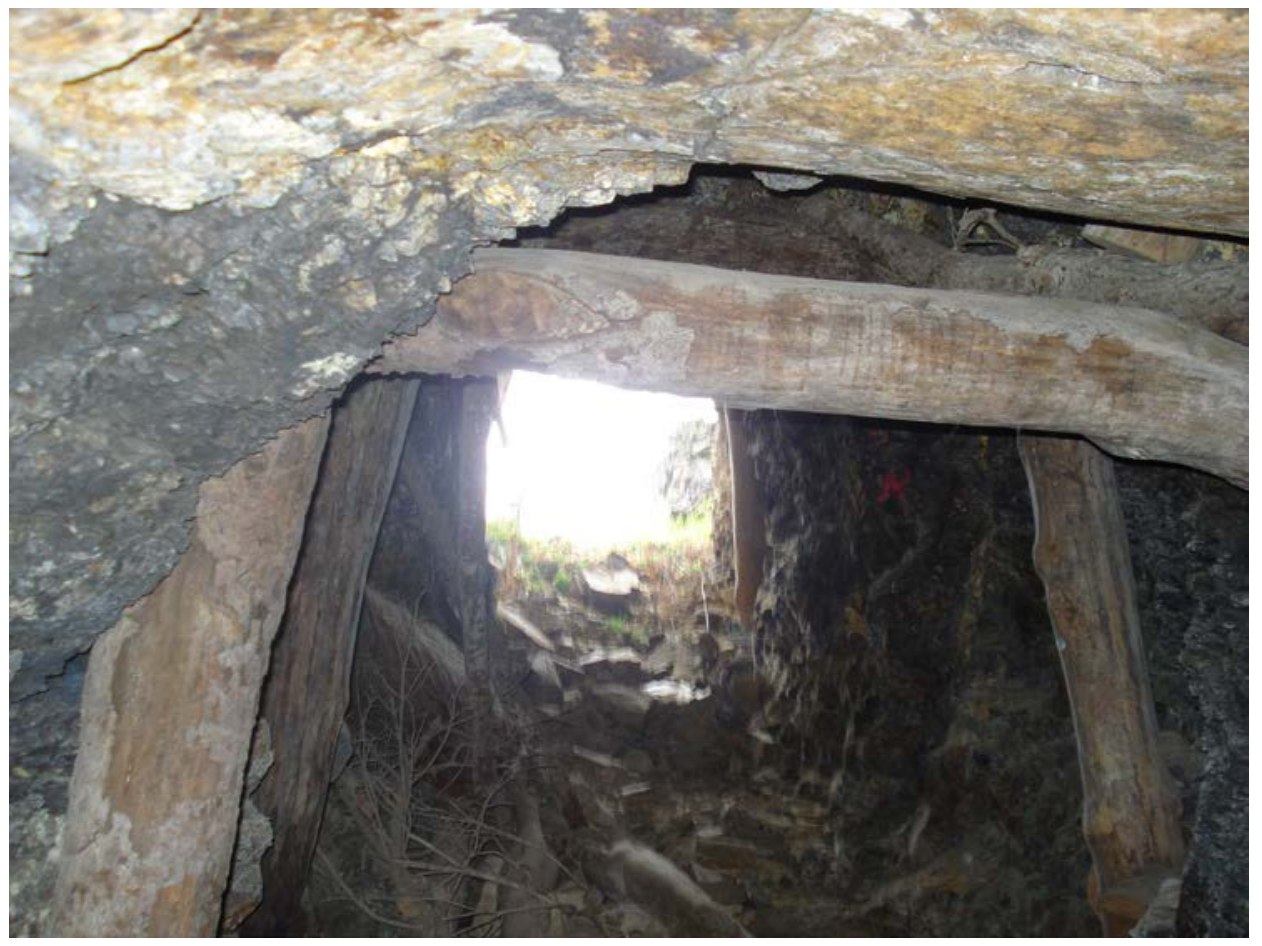

Fotografia 4. Un aspecte de l'interior de la Mina Serrana, entre afloraments de lidites del Carbonífer. El Molar 
L'altra galeria es troba situada a la part baixa d'un edifici dedicat als vins, que es va construir recentment. Al respecte, també es interessant visitar aquesta mina, molt semblant a l'anterior (PARADA 5 - BIS). Naturalment, per entrar-hi s'ha de tenir la oportuna autorització de l'empresa.

\subsection{Parada 6 - CONDICIONAL. ANTIGUES MINES DE "SABÓ DE SASTRE", (terme municipal del Molar, comarca del Priorat). (Full 471).}

Des de la parada anterior, cal seguir per la carretera camí que condueix directament cap el Molar, la T - 734. En arribar-hi, cal fer una fillola, agafant momentàniament la carretera $T$ - 731 (la qual condueix cap a Garcia). A menys de $1 \mathrm{Km}$ del Molar, ens cal agafar un camí per a dreta Per aquest camí, en quasi $1 \mathrm{Km}$, s'arriba a les antigues Mines de "Sabó de Sastre", on farem la present aturada, després de recórrer uns $6 \mathrm{Km}$, des de l'anterior.

En aquest recorregut, s' han anat tallant els nivells gresencs i lutítics eocens, ja esmentats a la parada anterior, els quals pertanyen a la Depressió de Mora, integrant també del Sistema Mediterrani.

Ara, en aquest indret, ens trobem davant dels afloraments d'aquests darrers materials. I entre aquests es troben un trams argilosos. amb presència de CAOLINITA i SAPONITA (o "sabó de sastre"). Precisament. aquest darrer mineral va ésser explotat en unes minetes, les quals es troben actualment enrunades.

\subsection{Parada 7. CARRETERA DEL MOLAR A BELLMUNT DEL PRIORAT, SOTA DEL POBLE. (Terme municipal del Molar, comarca del Priorat). (Full 471).}

Des de la parada anterior, cal retornar immediatament el Molar. En arribar al poble cal passarlo de llarg i sortir per la carretera que se'n va cap a Lloa (la T - 732), però immediatament, cal agafar el trencall que se'n va cap a Bellmunt del Priorat. Poc després de la primera baixada, cal fer aquesta parada, a uns $6 \mathrm{Km}$ de l'anterior. Concretament, aquesta parada, es situa a uns 0'3 $\mathrm{Km}$ m després de passar pel Molar (pel camí-carretera que se'n va cap a Bellmunt. Així, des de la parada anterior haurem recorregut uns $2 \mathrm{Km}$.

En aquest recorregut, hem anat creuant molt sovint els materials vistos a les parades anterior, així, sovint hem creuat els mantells al-luvionars quaternaris que vergeixen sobre la Depressió de Mora, situada a ponent de la carretera. Tot i que en aquest recorregut, en arribar prop del Molar, haurem estat circulant per la Depressió de Mora, de forma que els materials detritics quaternaris cobreixen als eocènics de la depressió, els quals afloren a ponent del poble. Tot $\mathrm{i}$ així, en arribar al poble, prop d'ell afloren els nivells detrítics rogencs del Buntsandstein. Aquests els anirem trobant fins a l'indret de la parada, on es troben els materials paleozoics del Carbonífer.

En aquest indret de la parada hi ha unes petites cates, fetes sobre un filó de BARITINA, que es troba encaixat entre els materials esquistosos del Carbonífer, en contacte amb uns pòrfirs granítics. Per sobre d'aquest, i afectats també per la falla, es troben els materials rogencs del Buntsandstein, que hem trobat baixant del poble. Així, part de la mineralització es troba associada a la paleosuperficie del Buntsandstein.

Entre els minerals presents, conjuntament amb la BARITINA (mot abundant), també es troben alguns sulfurs com la CALCOPIRITA i la TETRAEDRITA. Igualment, es troben diversos minerals d'alteració com els següents: COURE NADIU (indicis), CERVANTINITA, GOETHITA (limonítica), VALENTINITA, ATZURITA i MALAQUITA. I, tanmateix cal fer esment de la presència de dendrites de PIROLUSITA (de vegades molt abundants) i de la 
CALCIOVOLVORTITA (que aquí és l'únic indret de Catalunya on apareix). Tot i així, la BARITINA és el mineral més abundant i ostensible d'aquesta mineralització. (fotografia 5).

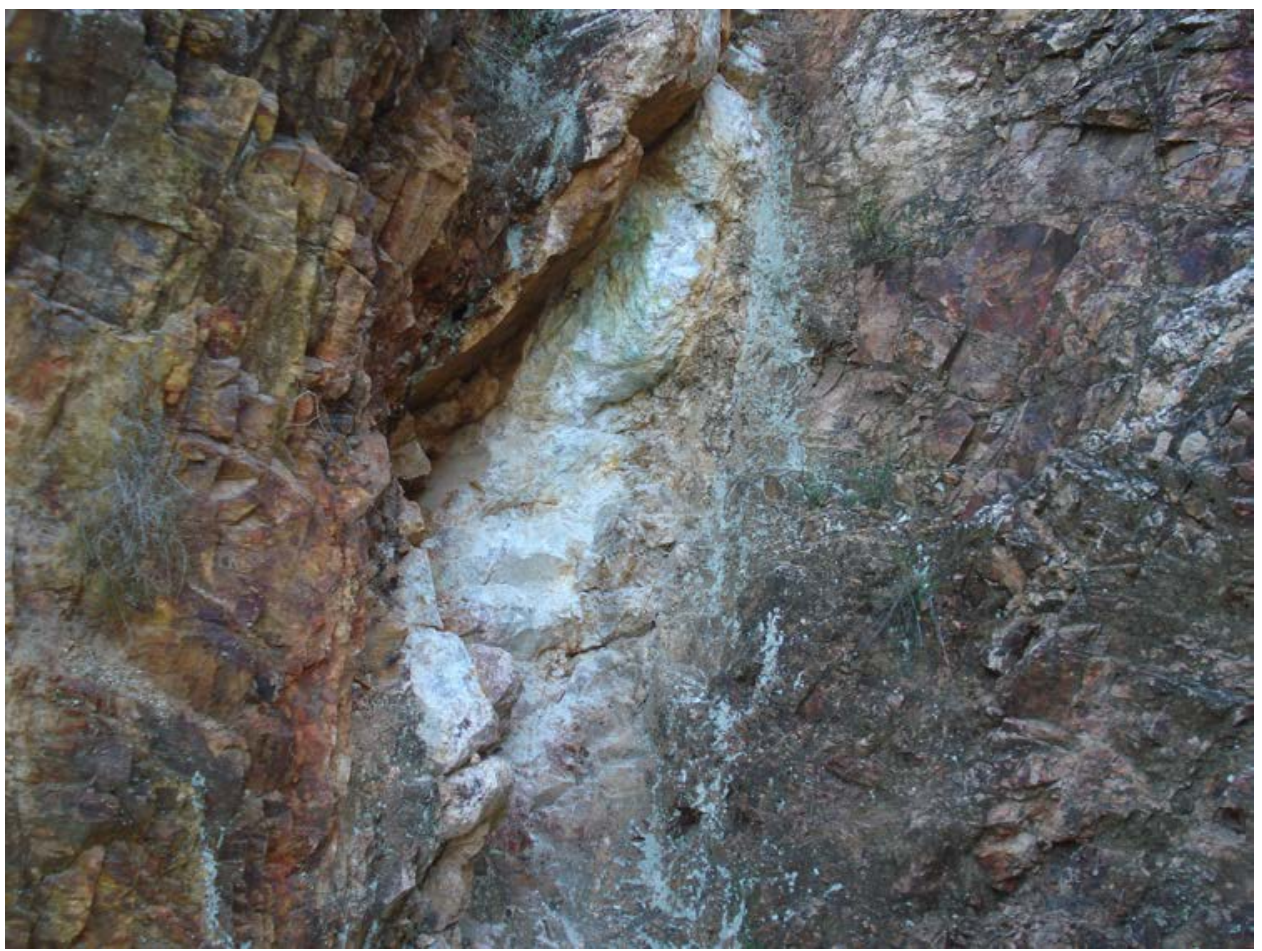

Fotografia 5. Us aspecte de la baritina, amb el filó. El Molar

\subsection{Parada 8. MINA RAIMUNDA. (Terme municipal del Molar, comarca del Priorat). (Full 471).}

Després de fer la parada anterior, cal fer un petit recorregut per la carretera que es dirigeix cap a Bellmunt del Priorat. Ben aviat, a l'esquerra de la ruta ens trobarem les instal.lacions de I'antiga Mina Raimunda. Aquí farem una nova aturada, a menys de $1 \mathrm{Km}$ de l'anterior.

En aquest breu recorregut, haurem anat trobant els afloraments dels materials paleozoics del carbonífer. Precisament, aquests materials paleozoics són els que es troben a l'indret de la parada. Tot i així, també es troben afloraments de leucogranits.

Per altra banda, a l'escombrera es fan força palesos els dos minerals explotats: GALENA i ESFALERITA (més minoritària). Com a minerals d'alteració es troben: ANGLESITA, CERUSSITA, GOETHITA (limonítica), i PIROMORFITA. També hi ha abundants mostres de dendrites de PIROLUSITA.

En aquest lloc, es fan paleses les instal.lacions de l'antiga Mina Raimunda, amb un interessant "castellet miner". Aquest es troba fet d'obra. Tot i així, també es troben les restes de l'antic "castellet metàl-lic" convertit en un amuntegament de runa. (fotografies 6 i 7). 


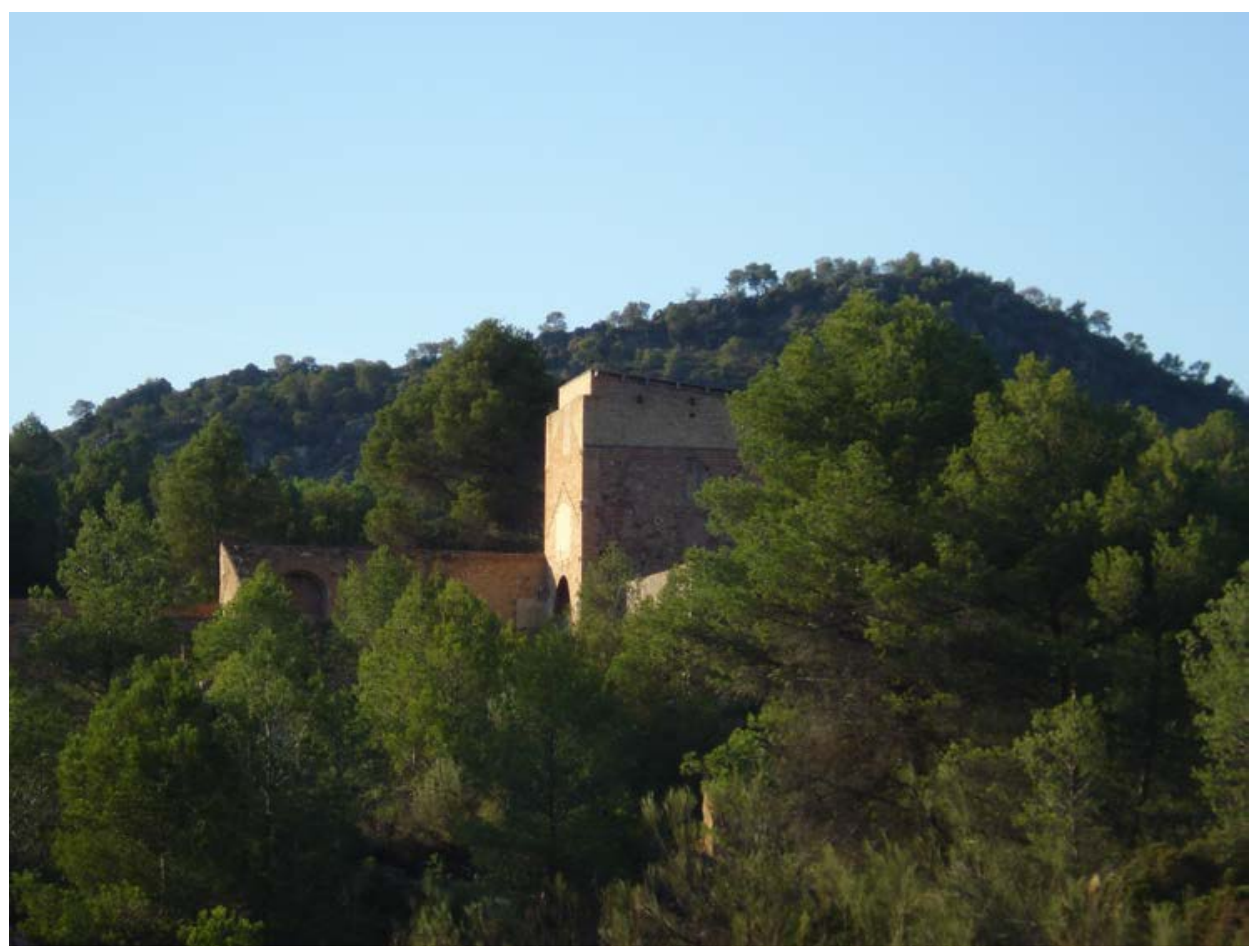

Fotografia 6. El castellet miner de la Mina Raimunda. El Molar

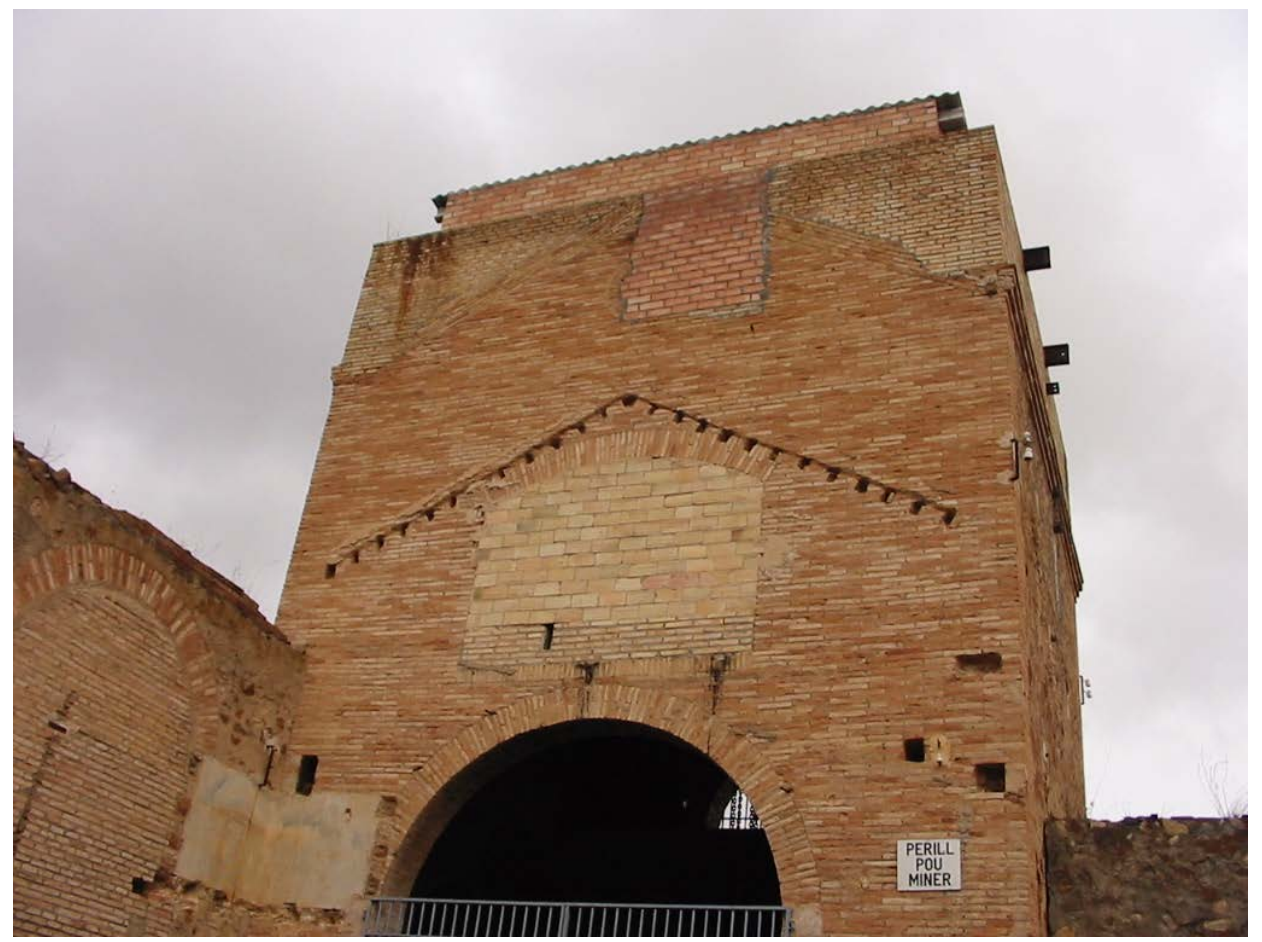

Fotografia 7. Un altre aspecte del castellet miner de la Mina Raimunda. El Molar Marçà, al Masroig, al Molar i a la Figuera de Falset 


\subsection{Parada 9 - CONDICIONAL. MINA JALAPA. (Terme municipal del Molar, comarca del Priorat). (Full 471).}

Després de fer l'aturada anterior )en cas d'haver-se fet), cal continuar uns $200 \mathrm{~m}$ per la carretera que es dirigeix cap a Bellmunt del Priorat. Ben aviat es trobaran les instal-lacions inferiors de la Mina Jalapa. Aquestes es troben a l'altra banda del torrent que segueix la carretera. En aquest indret, si s'escau, es pot fer una nova aturada.

En aquest breu recorregut, haurem anat trobant els afloraments dels materials paleozoics del carbonífer. Precisament, aquests materials paleozoics són els que es troben a l'indret de la parada. Aquests, com al cas anterior, es troben constituïts per nivells d'esquistos paleozoics del Carbonífer, amb presència d'abundants leucogranis. Per d'altra banda, aquí es fan palesos els nivells amb metapelites carboníferes. Aquestes es troben creuades per freqüents pòrfirs granítics molt alterats (silificats i/o caolinititzats).

Alhora, encaixats en uns $i$ en altres materials, es troben nombrosos filonets de potència centimètrica. Els filonets es troben mineralitzats. amb abundant GALENA i ESFALERITA (més minoritària). Com a minerals d'alteració es troben: ANGLESITA, CERUSSITA, GOETHITA (limonítica), i PIROMORFITA. També hi ha abundants mostres de dendrites de PIROLUSITA.

En aquest lloc, es fan paleses les instal.lacions de I'antiga Mina Jalapa, entre les quals destaca I impressionant "castellet miner" situat dalt de tot de la muntanya. Aquesta estructura es d'obra, com el que hem vist a la parada anterior; és a dir: a la Mina Raimunda. (fotografia 8).

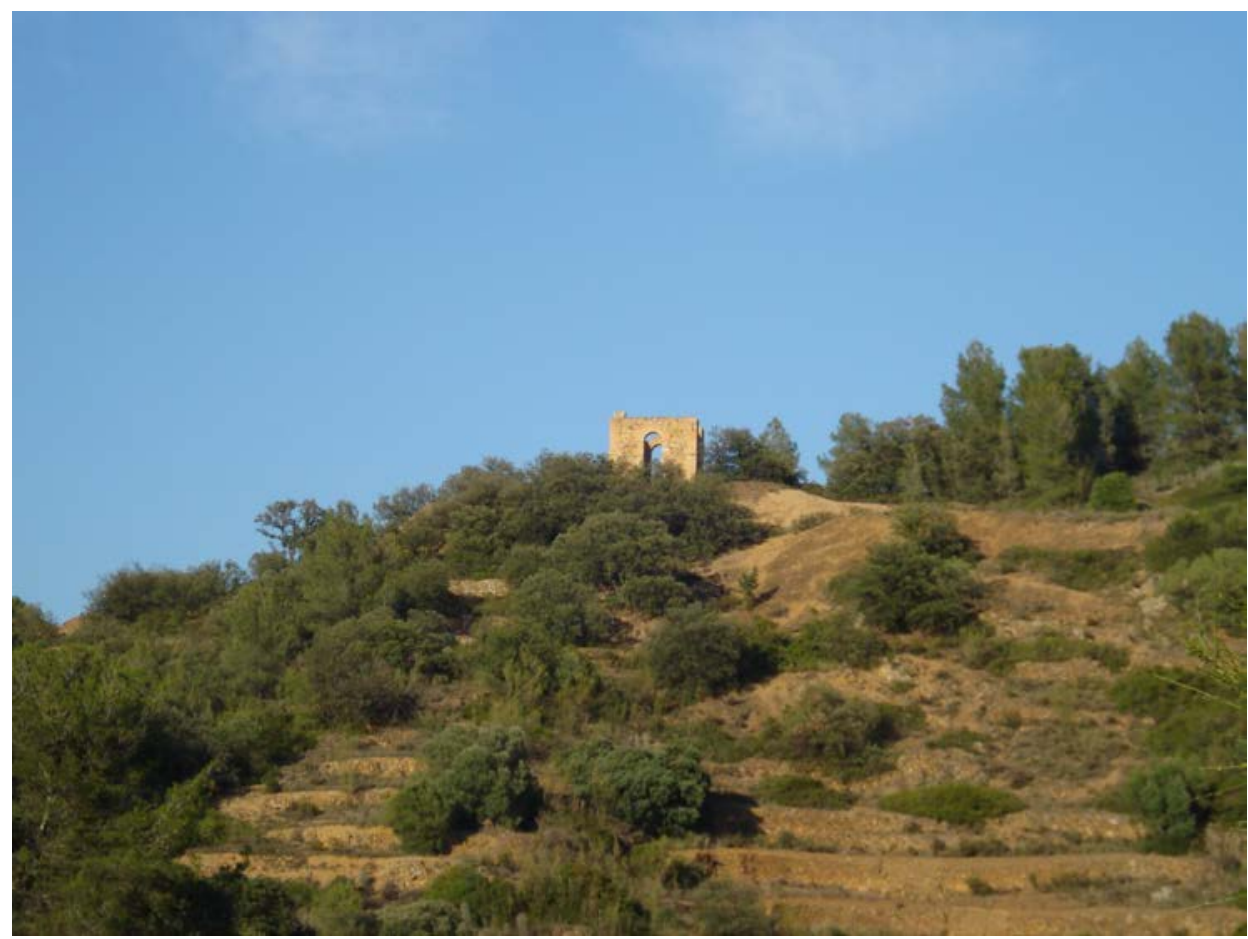

Fotografia 8. El castellet miner de la Mina Jalapa. El Molar 


\subsection{Parada 10. TALL OBERT DE LA MINA SANT JOSEP. (Terme municipal del Molar, comarca del Priorat). (Full 471).}

Després la parada anterior, cal continuar baixant pel camí - carretera que es dirigeix cap al poble de Bellmunt del Priorat. Quasi en arribar al riu (abans de trobar el trencall del Masroig), es trobarà un camí per l'esquerra. Aquest condueix cap a l'antiga Mina Mineralogia (on després farem una breu aturada), i cap a la recent Mina Sant Josep. En arribar a aquesta darrera, després d'haver efectuat un recorregut proper als $2 \mathrm{Km}$, des de la parada anterior, caldrà fer la present, si s'escau.

En aquest recorregut, hem continuat trobant sempre els materials paleozoics que hem trobat a les parades anteriors. Precisament, aquests materials paleozoics són els que es troben a l'indret de la parada. Així, enllà es fan palesos els nivells amb metapelites carboníferes. Aquestes es troben creuades per freqüents pòrfirs granítics molt alterats (silificats i/o caolinititzats).

Alhora, encaixats en uns i en altres materials, hi ha nombrosos filonets centimètrics mineralitzats. amb abundant GALENA i ESFALERITA (més minoritària). Aquests filonets es fan força palesos al tall obert (o cel obert). (fotografia 9).

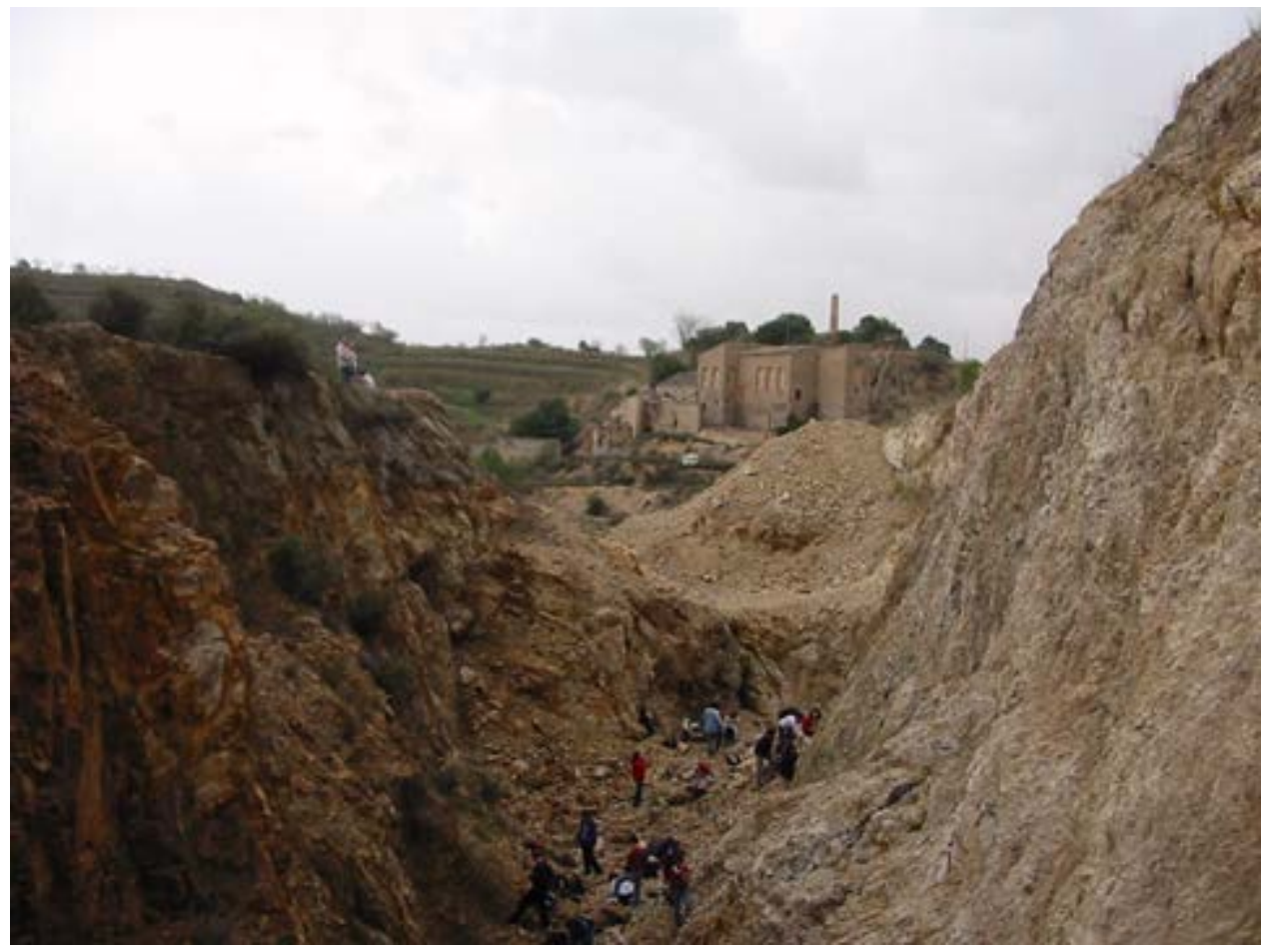

Fotografia 9. Un aspecte del tal obert de la Mina de Sant Josep. El Molar

Al fons es veuen les instal-lacions de la Mina Mineralogia 
Com a minerals d'alteració es troben: ANGLESITA, CERUSSITA, GOETHITA (limonítica), i PIROMORFITA. També hi ha abundants mostres de dendrites de PIROLUSITA. D'entre els minerals present al tall obert, cal fer esment de magnífics cristalls de cerussita, que sovint apareixen.

En aquest indret va haver-hi una explotació a cel obert, la qual ens ha permès veure els filonets en superfície. Actualment es troba tot aturat.

\subsection{Parada 11 - CONDICIONAL. MINA MINERALOGIA. (Terme municipal del Molar, comarca del Priorat). (Full 471).}

Després de fer l'aturada anterior, cal fer un breu recorregut, de menys de $0^{\prime} 2 \mathrm{Km}$, anant cap a llevant. Fins a la propera Mina Mineralogia. En aquest indret, si s'escau, farem una nova i breu aturada.

Com es natural, en aquest breu recorregut, hem continuat trobant els materials esmentats a la parada anterior. Aquests són també els que apareixen a l'indret de l'aturada.

Aquí hi ha mineralització semblant a la de la parada anterior. amb filonets centimètrics mineralitzats amb abundant GALENA i ESFALERITA (més minoritària). També es troben: ANGLESITA, CERUSSITA, GOETHITA (limonítica), i PIROMORFITA. També hi ha abundants mostres de dendrites de PIROLUSITA.

En aquest indret va haver-hi la darrera mina subterrània en explotació, de la qual es conserva encara el seu "castellet miner". Aquest es d'estructura metàl-lica, i va ésser el darrer en funcionament de tota la zona minera.

\subsection{Parada 12. MINA LINDA MARIQUITA. (Terme municipal del Molar, comarca del Priorat). (Full 471).}

Ara, des de la parada anterior, cal seguir pel camí asfaltat que es dirigeix a la carretera que enllaça Lloà amb el Molar (la carretera local $\mathrm{T}$ - 732). En trobar-la, caldrà continuar per aquest darrer poble. Després, en uns $2 \mathrm{Km}$ s'arribarà a les instal-lacions de l'antiga Mina Linda Mariquita, a quasi $0 ` 5 \mathrm{Km}$ del poble. En aquest indret farem una nova aturada, a uns $3 \mathrm{Km}$ de la parada anterior.

En aquest recorregut, hem anat circulant inicialment per entre els materials paleozoics anteriorment esmentats. Tot i així, en arribar a la carretera haurem incidit a la zona de contacte entre els materials paleozoics anteriors, i els terrenys mesozoics del Triàsic. Cal dir que la carretera anirà seguint pràcticament aquest contacte fins al propi indret de l'aturada.

En aquest indret hi ha un interessant patrimoni miner relacionat amb la darrera mina esmentada. Així, aquí es troben també les instal-lacions metal-lúrgiques, i també les antigues oficines de la companyia minera. (fotografía 10). 


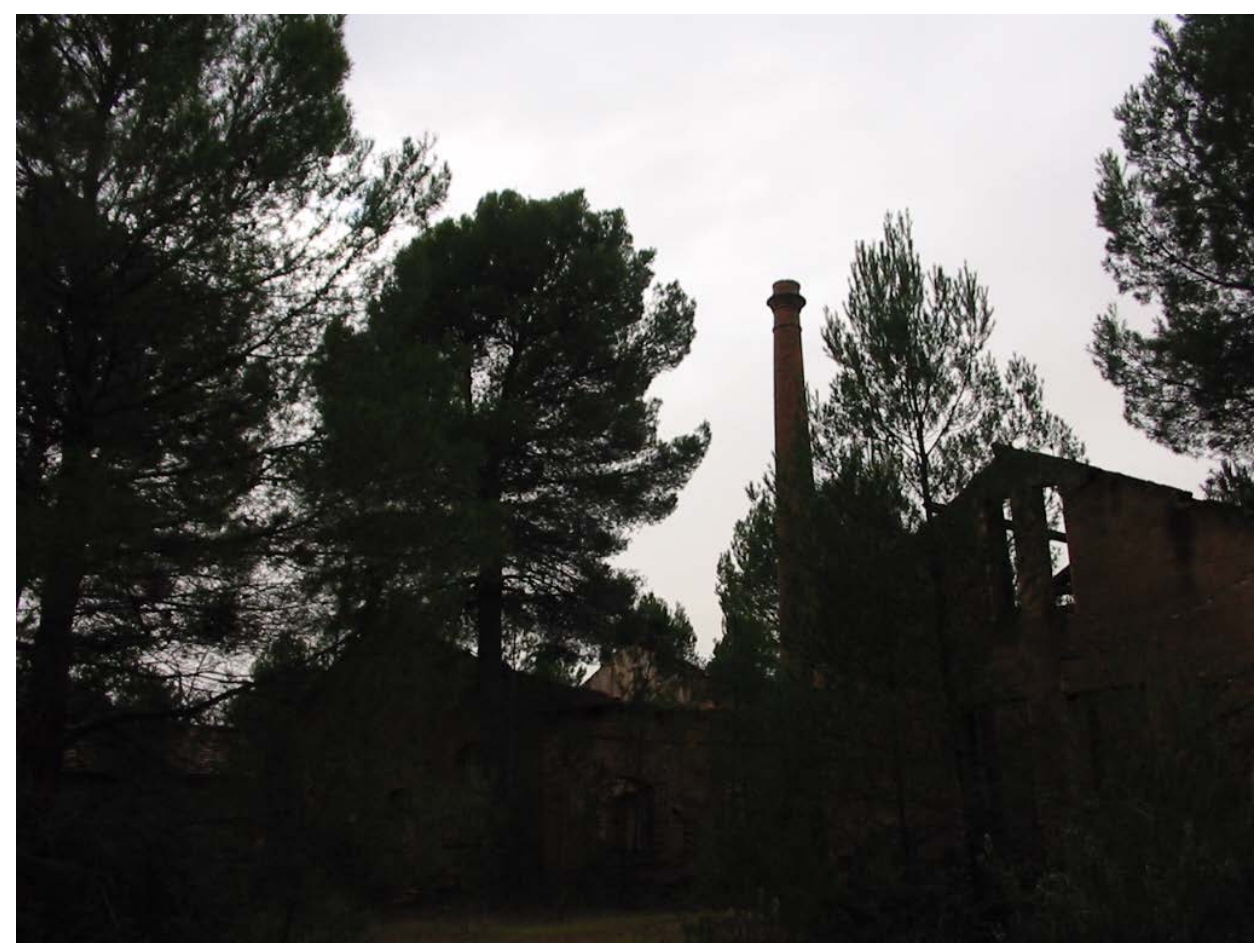

Fotografia 10. Restes de les instal-lacions de la Mina Linda Mariquita

Pel que fa a la mineralització, cal dir que es poden trobar tots els minerals esmentats a les parades anteriors. Cal recordar que també es tracta d'una mineralització filoniana de $\mathrm{Pb}-\mathrm{Zn}$, predominant la GALENA sobre I’ESFALERITA.

Finalment, cal dir que malgrat l'interessant patrimoni miner existent en aquest indret, aquest es comença a trobar molt malmès.

\subsection{Parada 10. MINA DE MANGANÈS DE LA SERRA D’ARANIT. (terme municipal de la Figuera de Falset, comarca del Priorat). (Full 471).}

Després de fer la parada anterior, cal seguir cap el Molar (seguint la carretera local T - 732), per a després agafar la carretera que duu al la Figuera, la carretera T - 730. Abans d'arribarhi, ens caldrà anar cap a la Serra d'Aranit, per on farem la darrera aturada del recorregut, a la Mina de Manganès.

En aquest recorregut des del Molar, hem anat trobant afloraments dels materials triàsics del Muschelkalk, els mateixos que hi a l'indret de la parada. Aquests materials formen part de la Branca Externa de la Serralada Prelitoral, per on estem ara. Prop d'aquí, cap a ponent, es troba la Depressió de Mora.

En aquest indret hi ha una mineralització de minerals de manganès de rebliment de cavitats d'origen kàrstic. La mineralització es troba entre les calcàries triàsiques del Muschelkalk Inferior.

Entre els minerals de manganès presents, cal fer esment dels següents: PIROLUSITA, PSILOMELANA, MANGANITA i MANGANOCALCITA. Amb ells es troben minerals de ferro, com: HEMATITES y GOETHITA. Per d'altra banda, la CALCITA es força abundant. 
En aquest indret finalitza el recorregut de l'itinerari

\section{Bibliografia}

GUIMERÀ, J. et altri (1992).- Geologia (II), Història Natural dels Països Catalans, Vol. 2, 547 pag. Enciclopèdia catalana, S.A., Barcelona.

IGME (1974a).- Mapa Geològico de España, a escala 1:50.000 (Segunda Série). Full i memòria $n^{\circ} \underline{411}$ (Mora d’Ebro). Ins. Tecnológico y GeoMinero de España. Minist. Indus. Energia. Madrid.

IGME (1974b).- Mapa Geológico de España a Escala 1:50.000 (2a Sèrie). Full i Memòria nº 472 (Reus). Inst. Tecnológico y GeoMinero de España. Minist. Indus. Ener. Madrid.

MATA-PERELLÓ, J.M. (1984).- Depressió Central o Depressió Geològica de I'Ebre ? Revista Dovella, 2ona. Ëpoca, nº 35, 12 pag. Manresa.

MATA-PERELLÓ, J.M. (1991).- Els Minerals de Catalunya Arxius de la Secció de Ciències, Vol XCIII, 444 pag. Institut d’Estudis Catalans, Barcelona.

MATA-PERELLÓ, J.M. (1996).- Itinerari geològic i mineralògic pel Baix Camp i pel Priorat: des de l'Aleixar a Cornudella, Porrera i al Molar. Inèdit. 6 pàg. Manresa.

MATA-PERELLÓ, J.M. (1997).- Recerca geològica i mineralògica per la comarca del Priorat: des de Cornudella a la Venta del Pubill, a Porrera i al Molar. Inèdit. 8 pàgines. Manresa.

MATA-PERELLÓ, J.M. (1998a).- Recerca geològica i mineralògica per les comarques del Baix Camp i del Priorat: des de les Borges del cap al Molar. Inèdit, 14 pàgines. Manresa.

MATA-PERELLÓ, J.M. (1998b).- Recorregut de recerca geològico-mineralògica i geo-ambiental per les comarques del Baix Camp i del Priorat: des de les Borges del cap al Molar per Pradell de la Teixeta. Inèdit, 18 pàgines. Manresa.

MATA-PERELLÓ, J.M. (1998c).- Recorregut de recerca geològica i mineralògica per les comarques del Baix Camp i del Priorat: des de l'Aleixar al Mas del Mestre, i des del Coll de la Teixeta al Coll de Falset i al Molar. Algeps, sèrie $B, n^{0} 125,16$ pàgines. Manresa.

MATA-PERELLÓ, J.M. (1999).- Recerca geològica i mineralògica per les comarques del Baix Camp i del Priorat: des de les Borges del Camp a Pradell de la Teixeta i al Molar. Algeps, sèrie $B, n^{\circ} 125,16$ pàgines. Manresa.

MATA-PERELLÓ, J.M. (2000a).- Recorregut de recerca geològica i mineralògica per les comarques del Baix Camp, de la Ribera d'Ebre i del Priorat: des de Reus a Mont-roig del Camp, a Tivissa i a Falset. Xaragall, sèrie $B, n^{\circ} 129,12$ pàgines. Manresa.

MATA-PERELLÓ, J.M. (2000b).- Recorregut de recerca geològica i mineralògica per les comarques del Baix Camp i del Priorat: des de Reus a Escornalbou i l'Argentera, i del Coll de la Teixeta al Coll de Falset i al Molar. Xaragall, sèrie $B, n^{\circ}$ 133, 18 pàgines. Manresa.

MATA-PERELLÓ, J.M. (2001).- Recorregut de recerca geològica i mineralògica per les comarques del Baix Camp i del Priorat: des del Coll de la Teixeta al Coll de Falset a Bellmunt del Priorat i al Molar. Algeps, sèrie B, $\mathrm{n}^{\circ}$ 194, 15 pàgines. Manresa. 
MATA-PERELLÓ, J.M. (2002).- Recorregut de recerca geològica i mineralògica per la comarca del Priorat: des de Bellmunt del Priorat al Molar. Xaragall, sèrie $B, n^{0} 173,15$ pàgines. Manresa.

MATA-PERELLÓ, J. M. (2003).- Recorregut de recerca geològica i mineralògica a través del patrimoni miner de la comarca del Priorat: des del Coll de Teixeta i Falset cap a Bellmunt del Priorat i al Molar. Inèdit. 10 pàg. Manresa.

MATA-PERELLÖ, J.M. (2004a).- Recorregut de recerca geològica, GEO ambiental i mineralògica a través del patrimoni miner de la comarca del Priorat: des de Falset cap a Bellmunt del Priorat i cap al Molar. Inèdit, 14 pag, Manresa.

MATA-PERELLÖ, J.M. (2004b).- Recorregut de recerca geològica, mineralògica i minera per la comarca del Priorat: des de Falset al Molar i a Bellmunt del Priorat. Inèdit, 12 pag, Manresa.

MATA-PERELLÓ, J.M. (2005a).- Recorregut de recerca geològica i minera per la comarca del Priorat: des de Falset a Pinyanes, a Bellmunt del Priorat i al Molar. Inèdit, 14pag. Manresa.

MATA-PERELLÓ, J.M. (2005b).- Recorregut de recerca geològica i minera per la comarca del Priorat: des de Falset a Bellmunt del Priorat; i des del Masroig al Molar. Inèdit. 16 pàgines. Manresa.

MATA-PERELLÓ, J.M. (2008).- Recorregut de recerca geològica i minera per la comarca del Priorat: des de Marçà al Masroig al Molar i a la Figuera de Falset. Inèdit. 12 pàgines. Manresa.

MATA-PERELLÓ, J.M. (2010).- Recorregut de recerca geològica i minera per la comarca del Priorat: des del Masroig al Molar. Inèdit. 10 pàgines. Manresa.

MATA-PERELLÓ, J.M. (2011).- Recorregut de recerca geològica i minera per la comarca del Priorat: des de Falset i del Masroig al Molar i a la Figuera de Falset. Inèdit. 10 pàgines. Manresa.

MATA-PERELLÓ, J.M. (2012).- Recorregut geològic i mineralògic per les comarques de la Terra Alta, Ribera d’Ebre i Priorat: des d'Horta de Sant Joan a Bot, Gandesa. Mora i al Molar. Inèdit. 14 pàgines. Manresa.

MATA-PERELLÓ, J.M. i COLLDEFORNS, B. (1994). Selecció d'itineraris geològics i mineralògics per les comarques del Baix Camp, Conca de Barberà, Priorat i Ribera d’Ebre. Xaragall, $\mathrm{n}^{\circ}$ 28, 36 pàgines. Manresa.

MELGAREJO I DRAPER J.C. (1992).- Estudio geológico y metalogenético del paleozoico del sur de las Cordilleras Costeras Catalanas. Memórias del Instituto Tecnológico y Geo-Minero de España , tomo 103, 605 páginas. Madrid.

RIBA ARDERIU, O. Et altri. (1976).- Geografia física dels Països Catalans. Edit Ketres, 205 pàgines. Barcelona. 